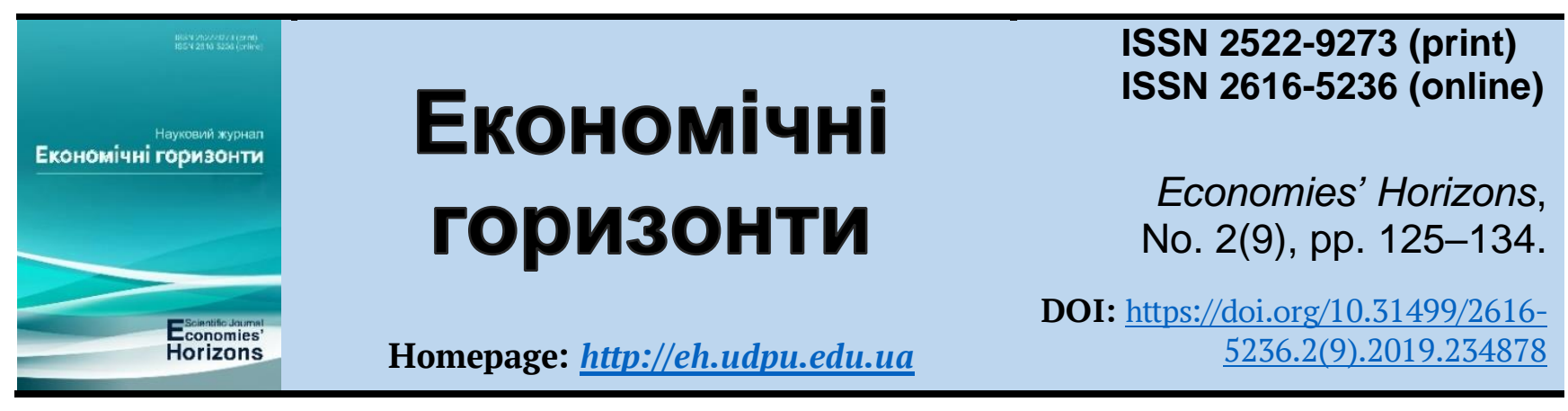

UDC 65.011.2:338.45

\title{
Structural and dynamic characteristics of the processes of digital transformation of national socio-economic systems
}

\author{
Received: 10 May 2019 \\ Accepted: 16 June 2019

\begin{abstract}
Vladyslav R. Rakipov ${ }^{1}$
Rakipov, V. R. (2019), "Structural and dynamic characteristics of the processes of digital transformation of national socio-economic systems", Economies' Horizons, no. 2(9), pp. 125-134, doi: https://doi.org/10.31499/2616-5236.2(9).2019.234878
\end{abstract}

Abstract. The aim of the article is to analyze the structural and dynamic characteristics of the processes of digital transformation of national socio-economic systems. Methodology. The theoretical and methodological basis of the study are the scientific works of scientists in the study of the digital transformation system. To achieve the goal set in the work, the following research methods were used: theoretical generalization - the main directions of digitalization; methods of statistical analysis - to characterize the structural and dynamic trends in the development of the information and communication technology sector in Ukraine. Results. In the context of accelerated digital transformation of global processes, the competitiveness of both the national economy as a whole and individual business entities depends on the ability to create, implement and effectively use digital technologies in all areas of operation. The analysis showed that Ukraine, despite the relatively late development of digital transformations and the definition of digital development as one of the priorities of public policy, has a high level of potential for the development of IT technologies. This is confirmed by the presence of highly qualified specialists in demand in the world's leading countries, the growth of exports of IT services, the accelerated growth of the internal market of information and telecommunications, the presence of sufficiently extensive communication infrastructure. A significant obstacle to the development of the national economy and accelerated digital transformation of business, in particular in the real sector, is the reduction of direct production of devices, devices and digital media (their specific weight in the industrial structure is only $2.5 \%$ and halved during 20122019). This causes a significant dependence of Ukraine on imported media, equipment for digital technologies and partially digital content, as well as the preservation of the low level of technological structure of the country as a whole. More positive are the trends in the digitalization of the services sector, which is more mobile in this context and focused on the continuous introduction, improvement and use of digital technologies, including the creation of intelligent market services, the specific weight of which is growing every year. Examining the development of digital technologies in Ukraine, we can identify the following main trends that combine macro-, meso- and micro-levels of socioeconomic systems in Ukraine and contribute to the accelerated transformation of the economy and society: the development of e-commerce; development of digital banking services and administration of public services. These areas are developing at an accelerated pace in recent years, outpacing the

\footnotetext{
${ }^{1}$ Higher Education Institution "International University of Business and Law"; Doctoral Candidate; ORCID ID: https://orcid.org/0000-0002-1386-5156; e-mail: management@nuos.edu.ua.
} 
pace of their development, even in some EU countries. Practical meaning. Data from the analysis of structural and dynamic trends in the development of the information and communication technology sector in Ukraine, which can be used by scientists, teachers and students. Prospects for further research. Overcoming certain major barriers to the development and dissemination of digitization processes in national systems.

Keywords: digital transformation, structural and dynamic characteristics, information and communication technologies, digitalization.

JEL Classification: L86, R10, R23.

Number of references: 9; number of tables: 4; number of figures: 0; number of formulas: $\mathbf{0 .}$

\section{Структурно-динамічні характеристики процесів цифрової трансформації національних соціально-економічних систем}

\section{Владислав Русланович Ракіпов ${ }^{1}$}

Стаття надійшла: 10.05.2019 Стаття прийнята: 16.06.2019
Rakipov V. R. Structural and dynamic characteristics of the processes of digital transformation of national socio-economic systems. Економічні горизонти. 2019. № 2(9). C. 125-134. DOI: 10.31499/2616-5236.2(9).2019.234878

Анотація. Метою статті $є$ аналіз структурно-динамічних характеристик процесів цифрової трансформації національних соціально-економічних систем. Методологія. Теоретичною і методологічною основою дослідження $є$ наукові праці вчених у дослідженні системи цифрової трансформації. Для досягнення поставленої в роботі мети були використані такі методи дослідження: теоретичне узагальнення - основні напрями діджиталізації; методи статистичного аналізу - для характеристики структурно-динамічних тенденцій розвитку сектору інформаційно-комунікаційних технологій в Україні. Результати. В умовах прискореної цифрової трансформації глобальних процесів, конкурентоспроможність як національної економіки загалом, так і окремих суб’єктів бізнес-середовища залежить від здатності створювати, впроваджувати та ефективно використовувати цифрові технології в усіх сферах функціонування. Проведений аналіз показав, що Україна попри порівняно запізніле становлення на шлях цифрових трансформацій та визначення цифрового розвитку у якості одного з пріоритетів державної політики, володіє високим рівнем потенціалу розвитку IT технологій. Це підтверджується наявністю висококваліфікованих спеціалістів, що затребувані в провідних країнах світу, зростанням експорту IT послуг, прискореним зростанням внутрішнього ринку інформації та телекомунікацій, наявністю достатньо розгалуженої інфраструктури зв'язку. Суттєвою перешкодою розвитку національної економіки та прискореної цифрової трансформації бізнесу, зокрема у реальному секторі, є скорочення безпосередньо виробництва приладів, пристроїв та носіїв цифрових технологій (іх питома вага в структурі промисловості складає усього 2,5 \% і скоротилася протягом 2012-2019 років у два рази). Це зумовлює суттєву залежність України від імпортних носіїв, обладнання для цифрових технологій та частково цифрового контенту а також консервування низького рівня технологічного укладу країни загалом. Більш позитивними $є$ тренди щодо діджиталізації сфери послуг, що $є$ мобільнішою у цьому контексті й орієнтована на постійне упровадження, удосконалення та використання цифрових технологій, зокрема і створення інтелектуальнонасичених ринкових послуг частка яких щороку зростає. Досліджуючи розвиток цифрових технологій в Україні можна виділити такі основні тренди, що поєднують макро-, мезо- та

\footnotetext{
${ }^{1}$ Заклад вищої освіти «Міжннародний університет бізнесу і права»; здобувач; ідентифікатор ORCID: https://orcid.org/0000-0002-1386-5156; e-mail: management@nuos.edu.ua.
} 
мікрорівні соціально-економічних систем в Україні та сприяють прискореним трансформаціям економіки і суспільства: розвиток електронної торгівлі; розвиток банківських цифрових послуг та адміністрування державних послуг. Дані напрямки розвиваються останніми роками прискореними темпами, випереджаючи при цьому темпи їх розвитку навіть в окремих країнах $€ \mathrm{C.} \mathrm{Практичне} \mathrm{значення.} \mathrm{Дані} \mathrm{аналізу} \mathrm{структурно-динамічних} \mathrm{тенденцій} \mathrm{розвитку} \mathrm{сектору}$ інформаційно-комунікаційних технологій в Україні, що можуть бути використані науковцями, викладачами та студентами. Перспективи подальщих досліджень. Подолання визначених основних бар'єрів розвитку і поширення процесів цифровізації в національних системах.

Ключові слова: цифрова трансформація, структурно-динамічні характеристики, інформаційно-комунікаційні технології, діджиталізація.

Кількість джерел: 9; кількість таблиць: 4; кількість рисунків: 0; кількість формул: 0.

\section{Introduction.}

The current stage of development of society and economic relations is characterized by the rapid development of digitalization processes, covering ever larger areas and niches of socio-economic systems. Under these conditions, the competitiveness of both the national economy as a whole and individual business entities depends on the ability to create, implement and effectively use digital technologies in all areas of operation.

\section{Literature review.}

Among modern economists, whose research is devoted to the problems of digital transformation of national socio-economic systems, it is necessary to note scientific works, in particular: I. Sheiko and O. Storozhenko (2019), M. Dubina and O. Sheremet (2019), G. Zhekalo (2019), I. Kramarenko (2015; 2017) and others. However, the complexity and versatility of this study requires a modern analysis of the structural and dynamic characteristics of the processes of digital transformation of national socio-economic systems.

\section{Methodology.}

The theoretical and methodological basis of the study are the scientific works of scientists in the study of the digital transformation system. To achieve the goal set in the work, the following research methods were used: theoretical generalization - the main directions of digitalization; methods of statistical analysis - to characterize the structural and dynamic trends in the development of the information and communication technology sector in Ukraine.

\section{Research objectives.}

The aim of the article is to analyze the structural and dynamic characteristics of the processes of digital transformation of national socio-economic systems.

\section{Results and discussions.}

Analyzing the dynamics of the main indicators of the development of the information and communication sector, it should be noted relatively slow but steady growth trends in its role in the national economy. In particular, for the period 2012-2019, the market growth rate was over $204 \%$, which is $75 \%$ faster than GDP growth, and the specific weight of the sector in GDP during this period increased by $0.5 \%$.

Structural and dynamic changes in the development of the information and communication sector in the national economy are shown in Table 1.

As you can see from the Table 1, for the period 2012-2019, sales of products and services in the field of information and communication technologies in Ukraine have doubled, and value added created in the sector by $181 \%$. Negative trends are the reduction in the number of employees in this area during the study period by $28 \%$, due to 2 reasons, namely: increased productivity due to the digitalization of a significant number of processes and the growth of shadow employment. In particular, according to DOU specialists monitoring the Ukrainian IT industry 
market, as of the end of 2019, more than 191,838 specialists are involved in the indus- try, which is $28 \%$ more than the data of the State Statistics Service.

Table 1. Structural and dynamic trends in the development of sector in the information and communication technology in Ukraine

\begin{tabular}{|l|c|c|c|c|c|c|c|}
\hline \multicolumn{1}{|c|}{ Indexes } & $\mathbf{2 0 1 2}$ & $\mathbf{2 0 1 5}$ & $\mathbf{2 0 1 6}$ & $\mathbf{2 0 1 7}$ & $\mathbf{2 0 1 8}$ & $\mathbf{2 0 1 9}$ & $\begin{array}{c}\text { Increase, } \\
\mathbf{\%}\end{array}$ \\
\hline $\begin{array}{l}\text { Sales volumes, UAH } \\
\text { million }\end{array}$ & $85,914.1$ & $117,826.0$ & $150,681.0$ & $188,042.0$ & $230,821.0$ & $261,481.0$ & +204 \\
\hline $\begin{array}{l}\text { Gross value added, UAH } \\
\text { million }\end{array}$ & $35,100.1$ & $48,340.6$ & $66,061.7$ & $76,553.4$ & $85,392.3$ & $98,448.7$ & +181 \\
\hline $\begin{array}{l}\text { Number of employees, } \\
\text { persons }\end{array}$ & 190,881 & $140,685.0$ & $132,158.0$ & $128,973.0$ & $127,941.0$ & $136,485.0$ & -28 \\
\hline & \multicolumn{2}{|c|}{ The specific weight in the national economy, \% } & & 2.7 & +0.7 \\
\hline $\begin{array}{l}\text { Sales volumes, UAH } \\
\text { million }\end{array}$ & 2.0 & 2.3 & 2.4 & 2.4 & 2.5 & 3.6 & +0.1 \\
\hline $\begin{array}{l}\text { Gross value added, UAH } \\
\text { million }\end{array}$ & 3.5 & 3.6 & 3.9 & 3.6 & 3.7 & 3.1 & -0.4 \\
\hline $\begin{array}{l}\text { Number of employees, } \\
\text { persons }\end{array}$ & 2.5 & 2.4 & 2.3 & 2.2 & 2.1 & 2.1 & +0.5 \\
\hline GDP, \% & 4.1 & 3.9 & 4.3 & 4.3 & 4.5 & 4.6 & +0.5 \\
\hline
\end{tabular}

Source: Calculated by the author according to the State Statistics Service of Ukraine (2019).

Table 1 show that despite the growing role of information and communication technologies in economic and social processes, in Ukraine the specific weight of this sector in the economy over the past 8 years has not increased significantly. Thus, the specific weight of the information and communication industry in Ukraine's GDP in 2019 was $4.6 \%$, which is $0.5 \%$ higher than in 2012, and in gross sales $-2.7 \%$ and increased by only $0.7 \%$. This indicates the insufficient pace of Ukraine's transition to a digital economy model and, at the same time, a significant amount of digital market in the shadow sector of the economy created as a result of insufficient institutional support and lack of effective legislation in this area.

The efficiency of development of the information and telecommunications sector in the national economy is characterized by the corresponding structural changes in the sector itself. According to the new approach to statistical accounting of economic activities provided for in Regulation (EU) № 251/2009 of 11.03.2009 on structural business statistics, the information and telecommunications sector includes:

1) Types of economic activity aimed directly at the creation, maintenance and technical support of information and communication links, as well as the production of digital products. Combines 3 groups of economic activities: namely:

- Information technology in production (NACE 26 - manufacture of computers, electronic and optical products), thus directly the creation of equipment for the use of digital technologies);

- Information technology in services, i.e. economic activities for the creation, implementation and maintenance of digital technologies (NACE 95.1 - Repair of computers and electronic equipment; 46.5 - Trade in electronic equipment and software; 58.2 software publishing; 61 - communications (telecommunications); 62 - computer programming, consultancy and related activities; 63.1 - Data processing, posting of information on web sites and related activities; web portals); 
Rakipov V. R. Structural and dynamic characteristics of the processes of digital transformation of national socio-economic systems

- Digital sector, i.e. types of economic activity, digital technologies in which are directly the main tool (Information sector (58.1. Publishing of books, periodicals and other publishing activities; 59.1 - Production of films and videos, television programs; 59.2 publishing of sound recordings; 60 - Activities in the field of radio and television broadcasting; 63.9 - Provision of other information services).

The structure of this sector primarily reflects the state of the national market of information and communication technologies and its dependence on imports. Table 2 shows the structural and dynamic characteristics of the development of information and communication technologies for the period 20122019 in Ukraine.

Table 2. Structural and dynamic characteristics of the development of information and communication technologies in Ukraine

\begin{tabular}{|c|c|c|c|c|c|c|c|}
\hline Period & 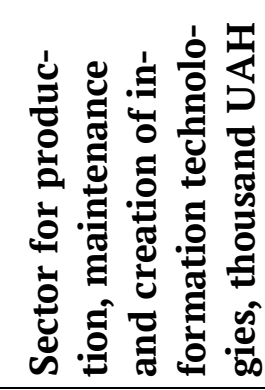 & 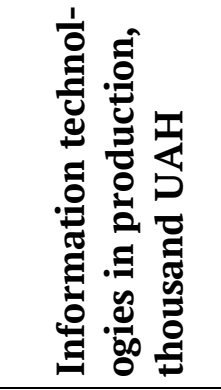 & 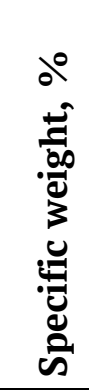 & 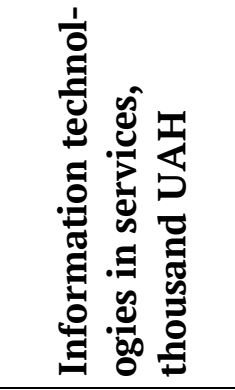 & 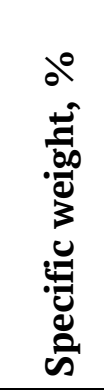 & 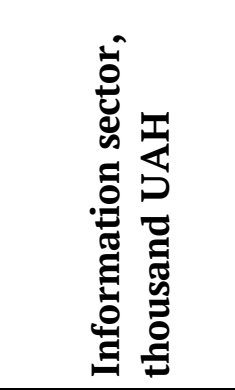 & 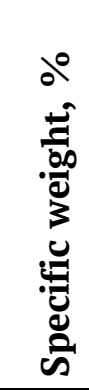 \\
\hline 2012 & $104,370,038.4$ & $5,388,037.0$ & 5.2 & $80,526,051.0$ & 77.2 & $18,455,950.4$ & 17.7 \\
\hline 2013 & $105,233,229.0$ & $5,063,315.7$ & 4.8 & $83,386,603.7$ & 79.2 & $167,83,309.6$ & 15.9 \\
\hline 2014 & $112,908,909.4$ & $5,082,241.7$ & 4.5 & $92,636,029.4$ & 82.0 & $15,190,638.3$ & 13.5 \\
\hline 2015 & $133,230,822.5$ & $4,538,955.1$ & 3.4 & $113,287,132$ & 85.0 & $15,404,735.3$ & 11.6 \\
\hline 2016 & $168,662,607.3$ & $6,349,730.7$ & 3.8 & $144,332,171$ & 85.6 & $17,980,704.7$ & 10.7 \\
\hline 2017 & $211,229,665.7$ & $6,637,843.8$ & 3.1 & $181,404,688$ & 85.9 & $23,187,133.1$ & 11.0 \\
\hline 2018 & $259,846,117.9$ & $8,588,476.9$ & 3.3 & $222,233,102$ & 85.5 & $29,024,538.5$ & 11.2 \\
\hline 2019 & $297,599,492.7$ & $7,497,363.6$ & 2.5 & $253,983,661$ & 85.3 & $36,118,468.1$ & 12.1 \\
\hline $2019 / 2012$ & +185.1 & +39.1 & -2.6 & +215.4 & +8.2 & +95.7 & -5.5 \\
\hline $2019 / 2018$ & +14.5 & -12.7 & -0.8 & +14.3 & -0.2 & +24.4 & +1.0 \\
\hline
\end{tabular}

Source: Calculated by the author according to the State Statistics Service of Ukraine (2019).

The structure of the information and communication technology sector is significantly dominated by digital technologies in services, the specific weight, \% of which at the end of 2019 was $85.3 \%$. During 20122019 , this area increased by $215 \%$, which indicates the intensification of the processes of digitalization of the economy and the mass introduction of digital technologies and software in the industrial and social spheres. As for the "hard component" of the studied sector, thus directly the production of devices, devices and carriers of digital technologies, their specific weight in the structure is only $2.5 \%$ and decreased during the study period by half. This indicates the gradual collapse of its own production of devices and equipment with the use of high technology. The information sector in Ukraine is $12 \%$ in 2019 and shows slight growth trends. That is, Ukraine has not yet achieved sufficient production of its own digital content. Thus, we can conclude that Ukraine is significantly dependent on imported media, equipment for digital technologies and partly digital content. At the same time, these trends are deteriorating in dynamics.

2) Types of economic activity that use information and communication technologies in production are divided into production using high-level technology, medium technology and low-level technology. The structure of 
this sector reflects the technological level of production in the national economy and the prevailing technological structure. In Table 3 the structural and dynamic characteristics of the industrial sector of the national economy in accordance with the level of applied technologies are given.

Table 3. Structural and dynamic changes in industrial production in the context of the level of applied technologies

\begin{tabular}{|c|c|c|c|c|c|c|c|}
\hline Period & $\begin{array}{c}\text { Volumes of } \\
\text { industrial } \\
\text { production, } \\
\text { thousand UAH }\end{array}$ & $\begin{array}{l}\text { Production } \\
\text { using high } \\
\text { technologies, } \\
\text { thousand } \\
\text { UAH }\end{array}$ & 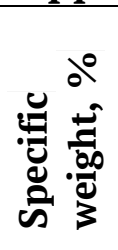 & $\begin{array}{c}\text { Production } \\
\text { using medium } \\
\text { level technolo- } \\
\text { gies, thousand } \\
\text { UAH }\end{array}$ & 选 & $\begin{array}{l}\text { Production } \\
\text { using low- } \\
\text { level technol- } \\
\text { ogies, thou- } \\
\text { sand UAH }\end{array}$ & 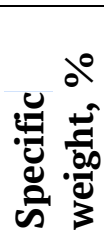 \\
\hline 2012 & $970,206,832.1$ & $34,679,401.9$ & 3.6 & $600,337,744.0$ & 61.9 & $335,189,686.2$ & 34.5 \\
\hline 2013 & $923,264,226.4$ & $35,604,959.4$ & 3.9 & $537,833,858.8$ & 58.3 & $349,825,408.2$ & 37.9 \\
\hline 2014 & $995,112,148.6$ & $40,230,545.9$ & 4.0 & $548,570,630.0$ & 55.1 & $406,310,972.7$ & 40.8 \\
\hline 2015 & $1,228,862,031.8$ & $50,311,488.9$ & 4.1 & $657,695,283.9$ & 53.5 & $520,855,259.0$ & 42.4 \\
\hline 2016 & $1,429,609,960.9$ & $57,556,690.4$ & 4.0 & $733,204,408.0$ & 51.3 & $638,848,862.5$ & 44.7 \\
\hline 2017 & $1,781,172,119.7$ & $68,846,165.2$ & 3.9 & $940,862,945.7$ & 52.8 & $771,463,008.8$ & 43.3 \\
\hline 2018 & $2,061,166,799.0$ & $75,731,613.6$ & 3.7 & $1,145,832,845.8$ & 55.6 & $839,602,339.6$ & 40.7 \\
\hline 2019 & $2,025,229,656.2$ & $7,4890,274.2$ & 3.7 & $1,089,782,428.3$ & 53.8 & $860,556,953.7$ & 42.5 \\
\hline $\begin{array}{l}2019 / \\
2012 \\
\end{array}$ & +108.7 & +116.0 & +0.1 & +81.5 & -8.1 & +156.7 & +7.9 \\
\hline $\begin{array}{l}2019 / \\
2018\end{array}$ & -1.7 & -1.1 & - & -4.9 & -1.8 & +2.5 & +1.8 \\
\hline
\end{tabular}

Source: calculated by the author according to the State Statistics Service of Ukraine (2019).

The structure of Ukrainian industry is dominated by economic activities that use mid-level technologies. Their specific weight in 2019 is 53.8 and decreased during the study period by $8.1 \%$ in favor of increasing economic activities using low-level technologies. The specific weight of production with the use of high technologies in Ukraine is only $3.7 \%$, which indicates a significant lag in the economy in terms of technology not only from European countries but also from most countries of the former CIS.

Structural changes in the economy are associated with the gradual reorientation of the economy to a predominantly agricultural direction of development, which in our opinion is a negative trend, hindering the high level of production and human potential. In this context, we agree with the Razumkov Center analysts that "at a time when progressive humanity seeks to move to the sixth technological mode with nanotechnology, nanomaterials, bioengineering and cognitive sciences, Ukraine is concentrated in the third technological mode of the last century, which includes more than $50 \%$ of all goods produced by us" (Pyshchulina, 2019). And this despite the fact that the country lacks neither specialists with higher education, nor doctors of sciences, nor annually registered patents.

3) Types of economic activity that use information and communication technologies in the formation of services (intellectually saturated market services, services using information technology and services using computer equipment). The structure of this sector shows the level of informatization and intellectual saturation of services created in the country. Table 4 illustrates the structural and dynamic changes in the development of services in the context of the formation, use and dissemination of digital technologies. 
Rakipov V. R. Structural and dynamic characteristics of the processes of digital transformation of national socio-economic systems

Table 4. Structural and dynamic changes in market of services in Ukraine in the context of digitalization

\begin{tabular}{|c|c|c|c|c|c|c|c|}
\hline Period & $\begin{array}{l}\text { Volumes of } \\
\text { production of } \\
\text { services, } \\
\text { thousand } \\
\text { UAH }\end{array}$ & $\begin{array}{l}\text { Intellectually } \\
\text { saturated } \\
\text { market ser- } \\
\text { vices thou- } \\
\text { sand UAH }\end{array}$ & की & $\begin{array}{l}\text { Services us- } \\
\text { ing infor- } \\
\text { mation tech- } \\
\text { nology, thou- } \\
\text { sand UAH }\end{array}$ & 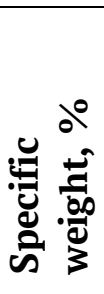 & $\begin{array}{l}\text { Services } \\
\text { using com- } \\
\text { puter } \\
\text { equipment, } \\
\text { thousand } \\
\text { UAH }\end{array}$ & 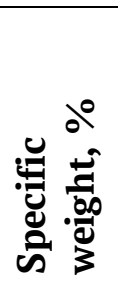 \\
\hline 2012 & $380,345,346.9$ & $90,890,380.9$ & 23.9 & $273,130,540.7$ & 71.8 & $16,324,425.3$ & 4.3 \\
\hline 2013 & $352,530,112.5$ & $90,409,589.8$ & 25.6 & $242,582,143.0$ & 68.8 & $19,538,379.7$ & 5.5 \\
\hline 2014 & $365,413,423.8$ & $92,452,512.6$ & 25.3 & $248,880,667.7$ & 68.1 & $24,080,243.5$ & 6.6 \\
\hline 2015 & $465,561,977.7$ & $110,250,309.5$ & 23.7 & $317,776,811.2$ & 68.3 & $37,534,857.0$ & 8.1 \\
\hline 2016 & $574,924,709.0$ & $127,359,908.9$ & 22.2 & $398,904,518.5$ & 69.4 & $48,660,281.6$ & 8.5 \\
\hline 2017 & $687,570,168.6$ & $150,459,569.9$ & 21.9 & $476,283,696.8$ & 69.3 & $60,826,901.9$ & 8.8 \\
\hline 2018 & $806,600,714.2$ & $185,176,262.3$ & 23.0 & $544,879,427.0$ & 67.6 & $76,545,024.9$ & 9.5 \\
\hline 2019 & $900,874,838.4$ & $218,065,819.9$ & 24.2 & $588,633,439.4$ & 65.3 & $94,175,579.1$ & 10.5 \\
\hline 2019/2012 & +136.9 & +139.9 & +0.3 & +115.5 & -6.5 & +476.9 & +6.2 \\
\hline 2019/2018 & +11.7 & +17.8 & +1.2 & +8.0 & -2.2 & +23.0 & +1.0 \\
\hline
\end{tabular}

Source: calculated by the author according to the State Statistics Service of Ukraine.

Analyzing the services market, it should be noted that the largest share in its structure is occupied by services using digital technologies (65.3 \%). Intellectually saturated market services also occupy a fairly representative niche $(24.2 \%)$. Their growth is positive both in the dynamics $(+139.9 \%)$ and in the structure of services $(+0.3 \%)$. In turn, services related to the use of computer equipment account for $10.5 \%$ and show accelerated growth, i.e. their volume has increased almost 5 times over the past 8 years. The results of the analysis showed that the services market is more flexible and mobile in the context of the development of digitalization processes and demonstrates sustainable economic growth. Structural and dynamic changes indicate the intensification of digitalization of the services sector and the rapid penetration of digital technologies in all areas: transport, communications, medicine, education, social environment, trade and more.

We agree with G. Zhosan that "over the last few years, the banking system has undergone major changes under the influence of digital technologies. The advantage of provid- ing digital services and exceptional interaction with customers were caused by the restructuring of the financial market, in particular the development of cryptocurrency, bitcoins and blockchains. The main directions of the modern banking system in terms of digitalization are:

- Digital transformation of bank transfers. This process becomes automated: now you do not need bank staff to make a transaction.

- Rethinking the banking business model. A good example is the use of blockchain technology (from the English "Blockchain"), which reduces fraud in the banking sector. It is already used in such operations as payments, direct investment transfers, trade and production management, mortgage, credit reports, etc." (Sheiko and Storozhenko, 2019).

In the context of the Pandemic Covid19 , the role of remote services in various areas, in particular in the financial sector, is significantly increasing. Banks of Ukraine started the transition to remote digital forms of customer service a long time ago. The first bank to introduce a remote Internet platform 
(Privat-24) in Ukraine in 2002 was Privatbank. Today, this bank occupies a leading position in customer service on the Internet, issues the largest number of payment cards and offers each customer free Internet banking, which has also developed into mobile banking. At present, all banks use various digital payment systems, mobile applications and online platforms to serve customers, as well as transfer some of their employees to remote work, which significantly reduces costs.

An important role in the development of banking institutions today is played by ebanking, among the ways of providing services which are divided into three forms:

1) services related to payments using bank cards;

2) internet banking;

3) mobile banking.

Today, Internet banking, mobile banking are the most popular and affordable forms of electronic banking. This is primarily due to the high share of non-cash payments and the desire of customers to quickly and reliably carry out financial transactions. According to GfK Ukraine surveys in 2018, $15 \%$ of the population uses the online banking version of the web, and $11 \%$ use the mobile version, in addition, $47 \%$ use the online banking of several banks. The most popular transactions carried out by customers in this area include the following: payment for utilities, mobile communications, money transfers and payment for goods and services (Dubina and Sheremet, 2019).

As noted by G. Zhekalo, "In practice, the digital economy is manifested primarily as a consumer-oriented economy (on-demand economy), i.e. the ability of the state to provide various services. In particular, it is the receipt by citizens of certificates, inquiries, statements, answers to inquiries in electronic form, even without leaving home, electronic payments and so on. In addition, it is a market for instant orders and unlimited selection of goods and services through the use of online stores, online banking, messengers or other social networks. The digitalization of the economy is taking place both through digital reforms in the spheres of public life - education, medicine, public administration, and directly in business" (Zhekalo, 2019).

At the same time, the level of digital literacy of the population of Ukraine remains low. According to a study conducted by the Ministry of Digital Transformation of Ukraine, $37.9 \%$ of Ukrainians aged 18-70 have digital skills below the basic level, and $15.1 \%$ - do not have them at all. That is, more than $53 \%$ of the population of Ukraine at the end of 2019 were below the "basic level" of digital literacy (Ministry of Digital Information of Ukraine, 2019).

One of the problems of digital transformation is the insufficiently regulated legal field of digital resources and the low level of digital awareness stimulates the development of fraudulent schemes using digital technologies. According to the survey, $34 \%$ of Ukrainians have become victims of fraud using the Internet.

With the strengthening of the decentralization process in Ukraine, the concepts of smart city ("smart" cities) are being actively implemented. About 7-10 cities in Ukraine already have relevant projects and initiatives.

The concept of a smart city is a model of the city using digital technologies to solve current problems of the city, its sustainable development and comfortable life of citizens.

According to the Concept of Development of Digital Economy and Society of Ukraine for 2018-2020 (Cabinet of Ministers of Ukraine, 2018), the most important issues for the development of the concept of smart city in Ukraine are the modernization of urban infrastructure and the introduction of effective resource management (using the Internet of Things, green technologies, smart grids); transformation of the city government system based on the integration of systems and data; the need to define economic models of urban development taking into account not 
only natural, industrial, but also human potential (cities as centers of innovation and human development).

Thus, the analysis of the main trends in the digital economy in Ukraine showed that despite some progress and significant potential, there are a significant number of problems hindering the transition of the national economy to a digital model of development. The main barriers to the development and diffusion of digitization processes in national systems are: financial constraints, unregulated institutional environment, the existence of territorial "digital divide", the development of the shadow market, digital security issues and low digital literacy and digital culture.

\section{Conclusions.}

With the accelerated digital transformation of global processes, the competitiveness of both the national economy as a whole and individual business entities depends on the ability to create, implement and effectively use digital technologies in all areas of operation. The analysis showed that Ukraine, despite the relatively late development of digital transformations and the definition of digital development as one of the priorities of public policy, has a high level of potential for the development of IT technologies. This is confirmed by the presence of highly qualified specialists in demand in the world's leading countries, the growth of exports of IT services, the accelerated growth of the internal market of information and telecommunica- tions, the presence of a sufficiently extensive communication infrastructure. A significant obstacle to the development of the national economy and accelerated digital transformation of business, in particular in the real sector, is the reduction of direct production of devices, devices and digital media (their share in the industrial structure is only $2.5 \%$ and halved during 2012-2019). This causes a significant dependence of Ukraine on imported media, equipment for digital technologies and partially digital content, as well as the preservation of the low level of technological structure of the country as a whole. More positive are the trends in the digitalization of services, which is more mobile in this context and focused on the continuous introduction, improvement and use of digital technologies, including the creation of intelligent market services, the share of which is growing every year.

Examining the development of digital technologies in Ukraine, we can identify the following main trends that combine macro-, meso- and micro-levels of socio-economic systems in Ukraine and contribute to the accelerated transformation of the economy and society: the development of e-commerce; development of digital banking services and administration of public services. These areas are developing at an accelerated pace in recent years, outpacing the pace of their development, even in some EU countries.

\section{References}

Cabinet of Ministers of Ukraine (2018), Order of the Cabinet of Ministers of Ukraine "The concept of development of the digital economy and society of Ukraine for 2018-2020", available at: https://zakon.rada.gov.ua/laws/show/67-2018-p\#T (Accessed 9 May 2019).

Dubina, M. and Sheremet, O. (2019), “E-banking development: World and domestic experience”, Problems and prospects of economics and management, no. 2(18), pp. 154-162, doi: http://dx.doi.org/10.25140/24115215-2019-2(18)-154-162.

Kramarenko, I. (2015), "Development of educational and social inclusion in conditions of social transformation of Ukraine”, Tiltai, vol. 72, no. 3, pp. 83-90, doi: http://dx.doi.org/10.15181/tbb.v72i3.1167.

Kramarenko, I. (2017), "Social-economic and intellectual development of Ukraine: Regional and national aspect”, Danish Scientific Journal, no. 1, pp. 20-27.

Ministry of Digital Information of Ukraine (2019), "Digital literacy of the population of Ukraine 2019", available at: https://osvita.diia.gov.ua/uploads/0/585-cifrova_gramotnist_naselenna_ukraini_2019 compressed.pdf (Accessed 9 May 2019). 
Pyshchulina, O. (2019), "Two sides of digital technology: "Digital dictatorship" or maintaining resilience", available at: https://razumkov.org.ua/statti/dvi-storony-tsyfrovykh-tekhnologii-tsyfrova-dyktatura-abozberezhennia-stiikosti (Accessed 9 May 2019).

Sheiko, I. and Storozhenko, O. (2019), "Effects of digitalization on Ukrainian economy", New stages of development of modern science in Ukraine and EU countries, Baltija Publishing, Riga, Latvia, 528 p. (pp. 473-491), doi: http://doi.org/10.30525/978-9934-588-15-0-46.

State Statistics Service of Ukraine (2019), "Statistical information", available at: http://www.ukrstat.gov.ua (Accessed 9 May 2019).

Zhekalo, G. I. (2019), "Digital economy of Ukraine: Problems and prospects of development”, Scientific Bulletin of Uzhhorod National University, vol. 26, part 1, pp. 56-60.

Цей твір ліцензовано на умовах Ліцензії Creative Commons «/з Зазначенням Авторства - Некомериійна 4.0 Міжнародна» (CC BY-NC 4.0). This is an open access journal and all published articles are licensed under a Creative Commons "Attribution-NonCommercial 4.0 International" (CC BY-NC 4.0). 